\title{
PENGARUH SENAM BAHU TERHADAP INTENSITAS NYERI DAN KEMAMPUAN KEMANDIRIAN AKTIVITAS FUNGSIONAL PADA PASIEN FROZEN SHOULDER
}

\author{
Wawan Ridwan Mutaqin, Ninik Nur Hidayah \\ Kementerian Kesehatan Politeknik Kesehatan Surakarta Jurusan Okupasi Terapi
}

\begin{abstract}
Frozen Shoulder are only used for a disease that is already well known that is characterized by pain and progressive stiffness in the shoulder that usually lasts 18 months. When it happened, and continues to be led to adhesions and joint capsule shrinkage and increased pain. The existence of pain can interfere in the conduct of daily functional activities, both in the area of self-care (self-care), productivity (productivity), and utilization of spare time (leisure). This study aims to determine the effect of exercise on the shoulder pain intensity and ability independence functional activity in patients with frozen shoulder. This study is an experiment with methods of the one group pretestposttest design. Sampling was done by purposive sampling at dr. Kariadi Hospital. The results showed that there are significant shoulder exercises for pain intensity and ability independence of functional activity in Frozen Shoulder patients at Dr. Kariadi Hospital significant with $p=0.000$. Based on age, the majority of respondents are elderly end as many as 13 people (52\%), the majority were female gender that 17 people (68\%), level of education is high school respondents largely a total of 11 people (44\%), and longsuffering majority still lacking of 6 months as many as 24 people (96\%). The implications of this study that shoulder exercises can be used as an alternative method in occupational therapy intervention in patients with frozen shoulder.
\end{abstract}

Keywords: Shoulder Exercises, Pain Intensity, Functional Activity Independence

Abstrak: Frozen Shoulder atau bahu beku hanya digunakan untuk penyakit yang sudah diketahui dengan baik yang ditandai oleh rasa nyeri dan kekakuan yang progresif pada bahu yang biasanya berlangsung 18 bulan. Bila hal itu terjadi dan berlangsung terus akan mengakibatkan perlengketan dan pengerutan kapsul sendi dan bertambah nyeri. Adanya rasa nyeri dapat mengganggu dalam melakukan aktivitas fungsional sehari-hari, baik pada area perawatan diri (self care), produktifitas (productivity), dan pemanfaatan waktu luang (leisure). Penelitian ini bertujuan untuk mengetahui pengaruh senam bahu terhadap intensitas nyeri dan kemampuan kemandirian aktivitas fungsional pada pasien frozen shoulder. Penelitian ini merupakan penelitian eksperimen dengan metode the one group pretest-posttest design. Pengambilan sampel dilakukan dengan purposive sampling di RSUP dr. Kariadi Semarang. Hasil penelitian menunjukkan bahwa terdapat pengaruh senam bahu terhadap intensitas nyeri dan kemampuan kemandirian aktivitas fungsional pada penderita Frozen Shoulder di RSUP Dr. Kariadi Semarang secara signifikan dengan nilai $\mathrm{p}=0,000$. Berdasarkan usia, mayoritas responden adalah lansia akhir sebanyak 13 orang (52\%), jenis kelamin mayoritas adalah perempuan yaitu 17 orang (68\%), tingkat pendidikan responden sebagian besar adalah SMA berjumlah 11 orang (44\%), dan lama menderita mayoritas masih kurang dari 6 bulan sebanyak 24 
orang (96\%). Implikasi penelitian ini bahwa senam bahu dapat digunakan sebagai alternatif metode dalam intervensi okupasi terapi pada pasien frozen shoulder.

Kata Kunci : Senam Bahu, Intensitas Nyeri, Kemandirian Aktivitas Fungsional

\section{PENDAHULUAN}

Dalam kehidupan sehari-hari, gerakan ekstremitas superior dalam beraktivitas merupakan gerakan yang sangat kompleks, tidak hanya bisa dilihat dari gerakan-gerakan halus dari jari-jari dan pergelangan tangan tetapi juga gelang bahu (shoulder girdle), lengan atas dan lengan bawah. Gerakan ektremitas superior akan tergantung kepada posisi dan gerakan gelang bahu dan tubuh, hal ini jauh lebih rumit dan kompleks daripada ektremitas inferior karena berkaitan dengan banyaknya tulang dan sendi yang terlibat, macam gerakan yang bisa dilakukan, koordinasi yang tinggi antar bagian sendi bahu dan tubuh.

Setiap orang menginginkan memiliki kapasitas fisik dan kemampuan fungsional yang baik untuk hidup produktif. Keinginan itu tidak mungkin terwujud jika seseorang mengalami nyeri pada daerah bahunya. Frozen Shoulder atau dikenal juga sebagai capsulitis adhesive merupakan salah satu manifestasi nyeri yang sering terjadi pada daerah bahu.

Frozen Shoulder atau bahu beku hanya digunakan untuk penyakit yang sudah diketahui dengan baik yang ditandai oleh rasa nyeri dan kekakuan yang progresif pada bahu yang biasanya berlangsung 18 bulan (Appley, 1995). Frozen Shoulder tidak berarti sendi bahu benar-benar "beku" karena kaku, tetapi lebih bersifat terlalu nyeri bila dipaksakan melakukan gerakan mencapai lingkup gerak sendi secara penuh. Pada kondisi ini ditemukan kapsulitis, disertai sedikit atau tanpa synovitis, tetapi tidak ditemukan arthritis, dapat ditemukan fibrosis jaringan perikapsuler, walaupun disebutkan ada inflamasi jaringan, tetapi laju endap darah (LED) tetap normal (Hudaya, 2002).

Secara epidemiologi Frozen Shoulder terjadi sekitar usia 40-65 tahun. Dari 2-5\% populasi sekitar $60 \%$ dari kasus Frozen Shoulder lebih banyak mengenai perempuan dibanding laki-laki. Frozen Shoulder juga terjadi pada 10-20\% dari penderita Diabetes Mellitus yang merupakan salah satu faktor resiko Frozen Shoulder (Sandor, 2004).

Berdasarkan data di Rumah Sakit Umum Pusat Dr. Kariadi Semarang, pada tahun 2011 sebanyak 124 pasien Frozen Shoulder menjalani terapi di unit okupasi terapi, dengan perincian 83 pasien perempuan, 41 pasien laki- laki. Pada tahun 2012 sebanyak 148 pasien Frozen Shoulder dengan perincian 95 pasien perempuan, 53 pasien laki-laki.

Penderita Frozen Shoulder mempunyai manifestasi antara lain adanya nyeri dan ketegangan otot pada sekitar daerah bahu yang terkena sehingga pasien mengeluhkan adanya keterbatasan pada lingkup gerak sendi pada bahu dan juga adanya penurunan kekuatan otot-otot pada bahu (Chory, 2009). Selain itu, hal yang mendasari terjadinya Frozen Shoulder adalah immobilisasi yang lama pada daerah bahu, adanya fraktur pada bagian bahu. Biasanya keluhan penderita Frozen Shoulder pada dasarnya adalah kesulitan dalam membentuk gerakan fleksi, abduksi, adduksi, eksternal rotasi dan internal rotasi (Chou, 2009). 
Akibat atau dampak yang terjadi pada penderita adalah gangguan pada aktivitas sehari-hari, produktifitas, dan leisure. Penderita biasanya cenderung takut untuk menggerakkan lengannya dan cenderung mempertahankan lengannya dalam posisi mendekati badan (adduksi). Bila hal itu terjadi dan berlangsung terus akan mengakibatkan perlengketan dan pengerutan kapsul sendi dan bertambah nyeri. Adanya rasa nyeri dapat mengganggu dalam melakukan aktivitas. Biasanya nyeri ini akan timbul saat melakukan aktivitas, seperti mengangkat tangan ke atas waktu menyisir rambut, menggosok punggung sewaktu mandi, menulis di papan tulis, mengambil sesuatu dari saku belakang celana, mengambil atau menaruh sesuatu diatas kepala dan kesulitan saat memakai atau melepas baju. Oleh karena itu sendi bahu harus dilatih baik dengan aktif maupun pasif (Suharto, 2008).

Okupasi terapi sebagai bagian dari profesi keterapian fisik mempunyai peranan penting dalam membantu dan melatih penderita Frozen Shoulder yang mengalami keterbatasan lingkup gerak sendi bahu, nyeri dan penurunan dalam aktifitas perawatan diri, produktifitas, dan leisure, salah satunya dengan senam bahu.

Latihan senam bahu secara aktif merupakan indikasi adanya aktivitas otototot scapula glenohumeral tanpa gerakan pada tubuh. Latihan aktif secara terukur, akurat dan rutin dengan toleransi rasa nyeri yang harus diperhatikan. Tujuan pokok senam bahu adalah : (1) mengurangi sakit dan spasme otot, (2) memelihara fungsi sendi bahu atau mencegah terjadinya gangguan fungsi sendi bahu secara fungsional, (3) menghilangkan gangguan fungsional yang telah terjadi, atau meningkatkan kemampuan fungsional sendi bahu semaksimal mungkin (Cailliet,1996).

Selama ini di unit Okupasi Terapi di RSUP Dr. Kariadi Semarang pelayanan yang diberikan pada kasus Frozen Shoulder antara lain: ADL training dan senam bahu. Namun sampai saat ini belum ada evaluasi mengenai dampak treatment Okupasi Terapi yang diberikan kepada pasien.

\section{METODE PENELITIAN}

Penelitian ini merupakan penelitian eksperimen semu dengan rancangan pretest-posttest. Dalam rancangan dilakukan pemilihan sampel, kemudian dilakukan pretest $(\mathrm{O} 1)$, diikuti intervensi $(\mathrm{X})$, dan posttest $(\mathrm{O} 2)$. Populasi dalam penelitian adalah semua pasien frozen shoulder di RSUP dr. Kariadi Semarang. Pengambilan sampel menggunakan teknik purposive sampling, dengan jumlah sampel 25 responden. Kriteria inklusi sampel adalah: 1). pasien frozen shoulder di RSUP dr. Kariadi Semarang yang mendapatkan pelayanan okupasi terapi, 2). hasil pemeriksaan VAS menunjukkan adanya nyeri, 3). mengalami gangguan kemampuan fungsional, dan 4). dapat memahami instruksi.

\section{HASIL PENELITIAN \\ Karakterisitik Responden Penelitian}

Dari 25 responden penderita Frozen Shoulder dalam penelitian ini didapatkan hasil bahwa berdasarkan usia dapat diketahui bahwa responden sebagian besar adalah lansia akhir berjumlah 13 orang (52\%), sebagian besar adalah perempuan berjumlah 17 orang (68\%), sebagian besar adalah SMA berjumlah 11 orang (44\%), sebagian besar menderita Frozen Shoulder $\leq 6$ bulan berjumlah 24 orang $(96 \%)$.

Deskripsi Tingkat Intensitas Nyeri 
Tingkat intensitas nyeri sebelum intervensi mayoritas responden merasakan tingkat intensitas nyeri sedang berjumlah 11 orang $(44 \%)$ dan kurang nyeri 9 orang $(36 \%)$, sedangkan setelah intervensi 4 responden $(16 \%)$ merasakan tidak nyeri, 1 responden (4\%) kurang nyeri, 6 responden (24\%) nyeri sedang, 14 responden (56\%) lebih nyeri, dan tidak ada responden yang merasakan sangat nyeri.

\section{Kemampuan Kemandirian Aktivitas Fungsional}

sebelum intervensi, mayoritas level kemandirian responden berada pada bantuan sedang berjumlah 11 orang (44\%) dan bantuan maksimal 9 orang (36\%). Sesudah dilakukan intervensi dengan senam bahu, 2 responden (8\%) pada level bantuan maksimal, 10 responden $(40 \%)$ bantuan sedang, 9 responden $(36 \%)$ bantuan sedang, dan 4 responden $(16 \%)$ membutuhkan "set up" setiap kegiatan.

\section{Uji Normalitas}

Uji normalitas menggunakan ShapiroWilk test karena jumlah sampel kecil (25 sample).

\begin{tabular}{lccc}
\multicolumn{4}{c}{ Tabel 1 } \\
Hasil Uji Normalitas Data \\
\hline Nilai & Statistik & df & Sig. \\
Kemandirian & 0.872 & 25 & 0.005 \\
\hline Sebelum & 0.876 & 25 & 0.006 \\
Sesudah & Statistik & df & Sig. \\
\hline Nilai Nyeri & 0.872 & 25 & 0.005 \\
\hline Sebelum & 0.841 & 25 & 0.001 \\
Sesudah &
\end{tabular}

Berdasarkan tabel 1 diketahui bahwa data berdistribusi tidak normal $(\mathrm{p}<0,05)$, maka uji statistik untuk menjawab hipotesis adalah mengunakan Wilcoxon Rank Test.

\section{Pengaruh senam bahu terhadap intensitas nyeri}

Berdasarkan hasil uji Wilcoxon Rank Test uji 2 sisi (asymp. Sig. 2-tailed) adalah 0,000, dibawah $0,05 \quad(0.000<$ $0,05)$. Jadi treatmen senam bahu memang mempunyai efek yang nyata untuk menurunkan intensitas nyeri responden.

\section{Pengaruh senam bahu terhadap} kemandirian aktivitas fungsional

Berdasarkan uji 2 sisi (asymp. Sig. 2tailed) adalah 0,000, dibawah 0,05 (0.000 $<0,05)$. Jadi treatmen senam bahu memang mempunyai efek yang nyata untuk meningkatkan kemandirian responden.

\section{PEMBAHASAN}

Berdasarkan hasil penelitian diketahui bahwa terdapat pengaruh senam bahu terhadap intensitas nyeri pada penderita Frozen Shoulder, hal ini dibuktikan dengan adanya penurunan intensitas nyeri sebelum dan sesudah senam bahu. Sebelum diberi latihan senam bahu, tingkat intensitas nyeri kategori nyeri sedang berjumlah 11 orang (44\%), kurang nyeri 9 orang $(36 \%)$, lebih nyeri 3 orang $(12 \%)$, dan sangat nyeri 2 orang $(8 \%)$. Sedangkan sesudah dilakukan latihan senam bahu, 4 responden (16\%) merasakan tidak nyeri, 1 responden $(4 \%)$ kurang nyeri, 6 responden $(24 \%)$ nyeri sedang, 14 responden $(56 \%)$ lebih nyeri, dan tidak ada responden yang merasakan sangat nyeri. Berdasarkan data di atas diketahui bahwa dari 25 responden 24 data bertanda negatif (ada penurunan intensitas nyeri setelah pemberian treatmen) dan 1 data sama (ties) tidak terjadi perubahan intensitas nyeri.

Hasil penelitian ini didukung dengan penelitian yang dilakukan oleh Lestaria Aryanti (1990), yang membandingkan tingkat nyeri dan lingkup gerak sendi yang dirasakan penderita Frozen Shoulder dengan hasil penurunan tingkat nyeri pada penderita Frozen Shoulder dengan 
dengan adanya latihan. Selain itu juga terdapat peningkatan kemandirian penderita dalam melakukan aktivitas yang merupakan dampak dari peningkatan lingkup gerak sendi penderita, baik fleksi, ekstensi, endorotasi maupun eksorotasi pada sendi bahu.

Menurut Cailliet (1996), latihan senam bahu secara aktif merupakan indikasi adanya aktivitas otot-otot scapula glenohumeral tanpa gerakan pada tubuh. Latihan aktif secara terukur, akurat dan rutin dengan toleransi rasa nyeri yang harus diperhatikan. Tujuan pokok senam bahu adalah: (1) mengurangi sakit dan spasme otot, (2) memelihara fungsi sendi bahu atau mencegah terjadinya gangguan fungsi sendi bahu secara fungsional, (3) menghilangkan gangguan fungsional yang telah terjadi, atau meningkatkan kemampuan fungsional sendi bahu semaksimal mungkin.

Mekanisme penurunan intensitas nyeri yang terjadi berhubungan dengan menurunnya spasme otot dan peningkatan sirkulasi darah pada otot. Hal ini sejalan dengan teori gerbang kontrol (gate control theory) yaitu efek dari latihan senam bahu. Senam bahu merupakan latihan sendi bahu secara aktif merupakan indikasi adanya aktivitas otot-otot scapula glenohumeral tanpa gerakan pada tubuh dan bertujuan penguluran jaringan lunak sekitar sendi yang mengalami pemendekan. Karena pada latihan senam bahu bertujuan untuk melakukan peregangan sendi bahu dan mengembalikan mekanisme persendian pada bahu. Latihan peregangan pada sesi pemanasan akan membantu relaksasi dari sendi bahu dan membantu pelumasan sendi bahu yang dapat memperbaiki kondisi celah sendi bahu yang menyempit. Pada latihan inti gerakan bahu kearah eksternal rotasi secara bertahap akan membantu memulihkan kelenturan dari kapsul sendi bahu yang sebelumnya mengkerut dan mobilisasi head of humerus (slide) ke arah inferior saat melakukan gerakan depresi akan membantu memfasilitasi terjadinya joint play movement saat pasien menggerakkan abduksi sendi bahu (Mujianto, 2012). Kemampuan otot apabila semakin sering dilatih maka cairan sinovial akan meningkat atau bertambah. Artinya, penambahan cairan sinovial pada sendi dapat mengurangi resiko cidera dan mencegah timbulnya nyeri bahu (Taslim, 2001). Berdasarkan keterangan di atas dapat disimpulkan bahwa senam bahu dapat berpengaruh menurunkan intensitas nyeri penderita Frozen Shoulder.

Berdasarkan penelitian diketahui juga bahwa terdapat pengaruh senam bahu terhadap kemandirian aktivitas fungsional. Hal ini dibuktikan dengan adanya perubahan level kemandirian bahwa dari 25 responden, 24 data bertanda positif (ada peningkatan kemampuan kemandirian aktivitas fungsional setelah pemberian treatmen) dan 1 data sama (ties) tidak terjadi perubahan kemampuan kemandirian aktivitas fungsional.

Hal ini sesuai dengan penelitian Jinglan Yang, dkk. (2007) bahwa secara keseluruhan, terjadi perbaikan secara signifikan pada pasien yan g mengalami latihan dan membantu seseorang untuk bergerak lebih leluasa. Caillied (1981), mengatakan bahwa manfaat senam bahu bagi penderita Frozen Shoulder antara lain mengurangi sakit dan spasme otot serta memelihara fungsi sendi bahu sehingga mencegah terjadinya gangguan fungsi sendi bahu secara fungsional. Senam merupakan latihan sendi bahu secara aktif merupakan indikasi adanya 
aktivitas otot-otot scapula glenohumeral tanpa gerakan pada tubuh dan bertujuan penguluran jaringan lunak sekitar sendi yang mengalami pemendekan. Selain itu senam bahu juga bermanfaat menghilangkan gangguan fungsional yang telah terjadi, atau meningkatkan kemampuan fungsional sendi bahu semaksimal mungkin.

Menurut Cauraugh (2005), aktivitas bilateral akan mengaktifasi jaringan neural di hemisfere pada sisi yang sama. Disamping itu bilateral training akan menurunkan interhemispheric inhibition dengan cara mengaktifasi kedua hemisfere bersama-sama (simultaneous). Hemisfere kanan dan kiri memiliki organisasi yang simetris untuk mengontrol tangan yang ada di korteks motorik dimana keduanya teraktifasi selama aktivitas.

\section{KESIMPULAN DAN SARAN}

Kesimpulan penelitian ini adalah terdapat pengaruh senam bahu terhadap intensitas nyeri dan kemampuan kemandirian aktivitas fungsional pada penderita Frozen Shoulder di RSUP Dr. Kariadi Semarang secara signifikan dengan nilai $\mathrm{p}=0,000$.

Saran untuk penelitian ini adalah agar penelitian lebih luas dengan jumlah sampel yang lebih banyak dan berkaitan dengan variabel-variabel yang berkembang dengan Frozen Shoulder.

\section{DAFTAR RUJUKAN}

Cailliet Rene. 1981. Shoulder Pain, Ed. 2, F.A. Davis Company, Hal. XII, 40 -41 .

Cailliet Rene. 1996. Soft tissue pain and disability F.A. Davis Company, Philadelphia.

Chory, F. 2009. Permasalahan pada bahu beku. Retrieved November
12,2009, dari http://tekaktekuk.blogspot.com/20 09/06/permasalahan-pada-bahubeku-frozen.html

Chory. 2009. Frozen shoulder. Retrieved November 16, 2009 dari http://xmrsmtaiping8286.wordpres s.com/category/financial-career/.

Chou, F. 2009. Pengertian frozen shoulder. Retrieved November 12,2009darihttp://ferrychou.blogsp ot.com/2009/01/frozenshoulder.html

Jing-lan Yang, Chein-wei Chang, Shiauyee Chen, Shwu-Fen Wang, Jiujenq Lin. 2001. Philadelphia Panel Evidence-Based Clinical PracticeGuidelines on Selected Mobilization Techniques in Subjects With Frozen Shoulder Syndrome: Randomized MultipleTreatment Trial. Physical Therapy Journal. PHYS THER. 2001; 81:1719-1730.

Mujianto. 2013. Cara Cepat Mengatasi 10 Besar Kasus Musculoskeletal dalam Praktik Klinik Fisioterapi. Jakarta. Cv. Trans Info Media.

Sandor, R. 2004. Adhesive capsulitis optimal treatment of frozen shoulder. Physician sportsmed. 28 (9): 23-29.

Suharto. 2008. Fisioterapi pada frozen shoulder akibat hemiplegia. Retrieved November 16, 2009 darihttp://binhasyim.wordpress.co $\mathrm{m} / 2008 / 01 / 22$ fisioterapi-pada frozen-shoulder-akibat-hemiplegia/ 